\title{
Astronomically aligned religious structures on Raiatea and Raivavae and the Matariki festival of 1770 on Easter Island $\dagger$
}

\author{
Edmundo Edwards \\ Pacific Islands Research Institute (PIRI), Casilla 27 Correro, Hanga Roa, Easter Island, Chile \\ email: eeastman04@gmail.com
}

\begin{abstract}
Eastern Polynesian astronomy was practiced by navigators and astronomer-priests who were in charge of adjusting the lunar calendar and their annual ritual cycle of activities known as 'The Work of the Gods'. The festivity known in Polynesia as Matariki, Matali' $i$ or Matari $^{i} i$ was related to the heliacal and acronical rising and setting of the Pleiades. A study of 75 marae on the island of Raivavae, Austral Islands and of 7 marae in the island of Raiatea, Society Islands shows that there are alignments towards important star positions associated with this ritual cycle. Their use as observatories has not been documented and therefore these alignments could have served solely ritual purposes. On Easter Island all information regarding the Matariki festival coincides with the arrival of a Spanish expedition in 1770.
\end{abstract}

Keywords. Polynesia, ritual cycle, marae, alignments, harvest festival, Pacific islands: Raiatea, Pacific islands: Raivavae, Pacific islands: Easter Island

\section{Generalities about Polynesian cosmogony and astronomy}

The Polynesians perceived the celestial sphere as several heavens superimposed above each other where different entities and gods lived. The stars, planets and constellations were the abode of gods, goddesses and other supernatural and immortal beings that had resided there from the beginning of time together with the deified spirits of chiefs (Handy 1927: 93). Some stars were just lights placed upon the void to direct the gods across the sky. The number of stars known to the Polynesians was impressive; anthropologist Maud Makemson recorded the names of 772 stars and constellations as well as several astronomical terms while working in different Polynesian islands.

The form and composition of the Polynesian constellations differed between Western and Eastern Polynesia: stars could be grouped differently to represent distinct things, or the same ones could be differently perceived. In Eastern Polynesia, the Milky Way had the form of a shark, and the tail of Scorpius was a fishhook. Other groupings represented a frigate bird and a lizard. One of the Polynesians' most important navigational aids in these southern waters was $N g a V a k a$, a double outrigger voyaging canoe formed by $\alpha$ and $\beta$ Centauri and Crux: the higher it appeared upon the horizon, the further south you were. These same stars were perceived differently in Tonga. The Southern Cross was called Toloa (wild duck) and $\alpha$ and $\beta$ Centauri were yams (Collocott 1922: 3). The position of the planets, especially Mars, in relation to certain stars or constellations could be a good or bad omen.

The Moon was the abode of Hina, an earth woman formed by the gods of creation who gave birth to mankind and is therefore considered the Polynesian 'Eve' (Tragear 1891: 155). After a fight with the gods she escaped into the sky and has dwelt since then in

$\dagger$ Invited keynote lecture at Main Conference 
the moon. Polynesians believed that they could see Hina beating bark cloth (tapa) upon an anvil in the full moon. The arrival of the full moon was very important because it was believed to be bursting with fertility; this was therefore the best time to plant and it was celebrated with singing and dancing in most parts of Polynesia.

Polynesian believed that the chiefs, who could trace their descent from the gods of creation, were endowed with a special power called Mana. Astronomer-priests or skywatchers and navigators or wayfinders were the second most respected individuals in Polynesian society. Although the astronomical knowledge of both skywatchers and wayfinders must have overlapped, it differed in practice.

\subsection{The navigator or wayfinder}

The wayfinder was held in high esteem due to his knowledge of navigation, which permitted him to search for new lands, to trade, to visit friends and relatives, and to partake in religious or secular festivities on different island groups. Wayfinders were trained in astronomy, meteorological phenomena, oceanography and animal behavior at a very young age. Working in different capacities during a voyage, a wayfinder would learn from his peers how to successfully explore the sea of islands that surrounded him. Wayfinders determined latitude using a Star Compass based on the declinations of principal stars. Polynesians were especially accurate at dead reckoning, being able to determine their distance from land by careful observation of the stars, currents and drift, winds, marine birds, etc. As demonstrated by the experimental voyages of the Hōkūle' $a$ and other oceanic outriggers of the Polynesian Voyaging Society, most of their expeditions must have been successful. Nevertheless, the observation of the night sky was not limited to navigation but served another important function carried out by the powerful skywatcher priests.

\subsection{Astronomer-priests or skywatchers}

Astronomer-priests (tohunga) on Mangareva and Easter Island were in charge of observing the sky. There is little mention of astronomer-priests elsewhere in Polynesia, although they must certainly have existed. A platform in Atituiti Ruga, Mangareva was "a key location used for solstitial observations that helped to calibrate the lunar calendar, determine the transitions between the two main seasons of the year, and to make predictions about the coming year's breadfruit harvest" (Kirch 2004b; Ruggles 2010: 74).

On Easter Island the tohunga lived with their acolytes in tupa - circular dwellings with a small tunnel-like doorway, sometimes oriented towards the rising or setting of specific stars or constellations that were important in determining the Rapanui annual calendar of activities. Each clan had several tupa, usually located near their ceremonial centers (ahu) or important resource areas. Skywatchers observed the night sky standing on top of a tupa's roof or other especially designated area. On Rapa Nui's Poike peninsula there is site where skywatchers observed the rising and setting of the Pleiades to calibrate the lunar calendar and change of seasons. It is not known whether the skywatchers had astronomical instruments, but celestial bodies depicted in petroglyphs associated with cupules and dotted lines may be a record of astronomical activities.

\subsection{The lunar calendar}

The Polynesian year was divided into thirteen months of which one would be 'thrown away' when the lunar year did not coincide with the annual rising of the Pleiades (solar year). Polynesians used a lunar calendar in which each month began on a full moon and each night carried a different name. Astronomer-priests were responsible for correcting the inherent seasonal and chronological shortcomings of a lunar year in order to establish the cycle of yearly activities effectively (Kirch \& Green 2001: 273). Polynesian languages 
share some of the same words for the names of the months, 'nights of the moon', etc., indicating a common origin tracing back to their ancestral Lapita culture (ibid.: 267-272).

The lunar year was divided into two seasons that were determined by the heliacal and acronical rising of the Pleiades, which in tropical Polynesia marked an annual cycle of alternating dry and wet seasons that served to determine the time for planting and harvesting of yams and other root crops. In addition, the names for the months and nights of the Polynesian lunar calendar recognized the moon's effects on the tides and marine ecosystem for each night of the year, thus determining the optimal times and places for fishing, marine foraging, and available marine resources at all times of year, year after year.

Since the arrival of migrating birds, turtles, and pelagic fish coincided with the acronical or heliacal rising or setting of certain stars or constellations, the astronomer-priests used these astronomical events to mark the arrival of migratory species and could foretell when they would come to each island. Thus the heliacal rise of Aldebaran marked the time for the breadfruit season in tropical Polynesia and the acronical rising of the Pleiades on November 16 marked the opening of the offshore tuna fishing season on the Society Islands, Tuamotu, Gambier and Easter Island. The heliacal setting of the Pleiades on April 16 marked the end of the tuna fishing season on all these islands.

\section{Astronomically aligned structures in Polynesia}

Until recently, few structures in Western Polynesia had been identified as having an astronomical alignment or a cardinal orientation. An exception is the trilithon in Tonga, which is oriented towards the June solstice (Ferdon 1987: 84). Recent work on outdoor temples (heiau) in the Hawaiian Islands has revealed more consistent practices of orientation, both cardinal and upon the rising of the sun and the Pleiades (Kirch 2004a; Ruggles 2007). In Eastern Polynesia, specifically in Mangareva and Easter Island, there are several places where specialized priests observed the solstice or the heliacal rising or setting of the Pleiades; several of their outdoor temples (marae, me 'ae or ahu) have an astronomical or cardinal orientation (Buck 1938: 57; Kirch 2004b). While carrying out fieldwork in French Polynesia it was observed that several structures on Raivavae and Raiatea appeared to have a cardinal orientation or else seemed to be aligned to the solstices, Aldebaran, Antares, and the Pleiades. This information is detailed below.

\subsection{Astronomically aligned marae on Raivavae (Austral Islands)}

Raivavae is located in the Austral Island archipelago, $500 \mathrm{~km}$ south of Tahiti, and sits on the Tropic of Capricorn. It is a small high island that was surveyed by our team between 1989 and 1991 (Edwards 2003). During our survey, we only noted the structures that had a cardinal orientation, but a later study carried out by astronomer Louis Cruchet (Cruchet 2009) showed that several of these structures had significant orientations. These are listed in Table 1.

The fact that 15 of Raivavae's marae are oriented towards the rising point of Aldebaran, and 10 of them towards the setting point of Antares, cannot be coincidental, and must be part of a ritual cycle of ceremonies and agricultural activities marked by these stars. This needs further study.

\subsection{Astronomically aligned marae on Raiatea (Society Islands)}

During our archaeological survey of the Valley of Faaroa on Raiatea in 1986 (Edwards 1987), our team found 7 distinctive extended family household settlements associated with a large irrigated terrace complex that occupied the western part of the caldera. 
Table 1. Orientations of marae on Raivavae.

\begin{tabular}{|c|c|c|c|c|c|c|c|c|c|c|c|}
\hline \multicolumn{3}{|l|}{ Type B-1 } & \multicolumn{3}{|l|}{ Туре В-3 } & \multicolumn{3}{|l|}{ Type B-3a } & \multicolumn{3}{|l|}{ Type B-4 } \\
\hline Aldebaran & rise & 4 & Aldebaran & rise & 7 & Antares & set & & Aldebaran & rise & 3 \\
\hline Antares & set & 1 & Antares & set & 6 & Pleiades & set & 1 & Antares & set & 1 \\
\hline Not determined & & 2 & Alphard & rise & 1 & Procyon & set & 1 & Alphard & rise & 1 \\
\hline & & & Alphard & set & 2 & Cardinal & & 2 & Alphard & set & 1 \\
\hline Туре B-2 & & & Capella & rise & 2 & Not determined & & 0 & Pleiades & set & 3 \\
\hline Aldebaran & rise & 1 & Capella & set & 1 & & & & Spica & rise & 1 \\
\hline Antares & set & 1 & Pleiades & set & 1 & & & & Cardinal & & 3 \\
\hline Capella & rise & 1 & Procyon & set & 2 & & & & Not determined & & 7 \\
\hline Dubhe & set & 1 & Spica & rise & 1 & & & & & & \\
\hline Pleiades & set & 2 & Spica & set & 1 & & & & & & \\
\hline Spica & rise & 1 & Cardinal & & 1 & & & & & & \\
\hline Not determined & & 2 & & & & & & & & & \\
\hline
\end{tabular}

Table 2. The orientation of religious structures or marae in the Faaroa Valley.

\begin{tabular}{lclrl}
\hline Zone & Site no. & Ahu axis & Azimuth & Astronomical event \\
\hline C-III & 12 & Perpendicular & $63^{\circ}$ & June Sunrise or Pleiades \\
C-III & 7 & Parallel & $108^{\circ}$ & December Sunrise \\
A-II & 266 & Parallel & & Betelgeuse Rise \\
& & $64^{\circ}$ & June Sunrise or Pleiades \\
A-I & 71 & Perpendicular & $108^{\circ}$ & December Sunrise \\
A-I & 72 & Perpendicular & $108^{\circ}$ & December Sunrise \\
A-I & 121 & Perpendicular & $180^{\circ}$ & North-South \\
C-IV & 1 & Parallel & $112^{\circ}$ & December Sunrise \\
\hline
\end{tabular}

Each of these settlements had one or more religious structures (marae) associated with it. With the help of astrophysicist Malcolm Clark, we discovered that 6 marae may have had an astronomical orientation, including one with a possible astronomical orientation in each axis, while another was cardinally oriented (Table 2). There were four possible alignments upon sunrise at the December solstice, two towards sunrise at the June solstice or the rising position of the Pleiades, and towards to the rising position of Betelgeuse. A further two marae were oriented towards Raiatea's highest peaks.

There is no evidence that astronomer-priests in Eastern Polynesia used marae as astronomical measurement devices, however. They probably used them to celebrate rituals that were marked by the acronical or heliacal rising or setting of the celestial bodies associated with the marae in question. We can assume, then, that these alignments served purposes such as enhancing the fertility of the principal crops or augmenting the psychic powers derived from the astronomical events. The heliacal rising of Aldebaran together with that of the Pleiades $\left(\right.$ Matari $\left.^{6} i\right)$ predicted the ripening of breadfruit and signalled a time of abundance in the Society Islands; this is probably why several marae in these islands were oriented perpendicular or parallel to the place in the sky where those asterisms were first seen at the time of their heliacal rising.

\section{The celebration of the Matariki festival on Rapa Nui, November 16, 1770}

On Rapa Nui, as in all of Polynesia, the bountiful season (Hora Nui) began with the acronical rising of the Pleiades (Matariki) when they appeared for the first time after twilight on November 16. This period lasted 4 months during which normal labor was suspended, offshore fishing restrictions (Rahui) were lifted, and large schools of tuna fish 
migrated past the island. It was one of the most important times of the year, a time when the first harvests were offered to the chiefs and joyful ceremonies were held to honor the deified ancestors for their generosity and support.

Ethnographic sources indicate that important astronomer-priests must have been staying in a cave on the eastern side of Maunga Vai a Heva (Hevas water), the highest lava dome of Pua Katiki volcano, on Poike peninsula, during the nights before and after the Matariki festival. This author was told that a very powerful priest called Heva had lived there in the company of other astronomer-priests, all of whom were considered to be the foremost wise men of the island. Together they had built several small ceremonial platforms with trachyte stone statues on each of the domes and also near the base of the cave, so that the whole area was considered sacred. They must have been surprised, as was everyone else on the island, to see two large ships looming over the horizon shortly after sunrise on November 15, 1770.

Forty-eight years had passed since the first European explorers landed on Rapa Nui in early April 1722; it was forty-eight years since the Rapanui had seen muskets and witnessed the first deaths by gunfire. Captain Felipe González de Haedo, commanding the Santa Rosalía with 70 cannons together with the frigate San Lorenzo with 30 more, arrived with a total of 814 men in what would be the Rapanui's second contact with outsiders after Jacob Roggeween's disastrous exchange decades before. After circling the island for a whole day with many islanders gathering on the shore, the Spanish launched some small boats to find anchor at 8 am on November 16 (Mellen Bianco 1986).

Aside from the obvious excitement with which the Spanish were greeted, there are several indications that this was a special time of the year for the Rapanui. The Spanish recorded seeing many people painted with white, yellow, and mostly red pigments - red being the colour that most attracted their attention; in addition, the 'important men' had their entire bodies painted bright red with drawings of chickens and 'very ugly faces' on their abdomens. Red was the colour of sacredness throughout Polynesia, which is why it would have been particularly important during these festivities, while the chickens were probably symbolic of the bountiful season or fertility. The figures painted on the abdomen - the seat of knowledge for Polynesians - probably represented the face of Make Make, the Rapanui creator god. Although it was customary for the Rapanui to decorate their bodies with paint, it seems that the common themes observed by the Spanish were more than just accidental. The Spanish also recorded seeing a figure called Ko Peka that was about $3.5 \mathrm{~m}$ long, stuffed with dried grass, and with hair made out of dark bulrushes. According to the Spanish, the Rapanui carried it to their different gathering sites and it was meant for amusement. Obviously this was not a figure that was put together overnight and if the Spanish were correct it was probably used in the first harvest feasts. Furthermore the Spanish were not met with any degree of hostility but with much excitement, rejoicing, and merriment; they were offered chickens, bananas, and several kinds of tubers, while one small group that ventured inland was conducted to a chief's house or meeting house where the Rapanui sang and danced for them. This may be interpreted as the islanders' natural generosity and cheerful disposition, but it is also possible that, for the Rapanui, these were offerings and honours they were paying to the 'gods'. This seems to be the case, especially since all Eastern Polynesians believed that during the Matariki Festival certain 'gods' descended from the ao (skyworlds) and mingled with ordinary people in the kainga (world of the living). Although only a few small Spanish groups had explored the island so far, revolving shifts of as many as 400 Rapanui at a time gathered aboard the San Lorenzo over the course of the next two days. The cultural impact of the Spanish explorers' visit would clearly not have been as tremendous had they arrived at a different time of the year. However it multiplied 
twofold when the Spanish decided to perform a magnanimous ceremony of their own on November 20, adding a whole other dimension to the festival.

At half past four in the morning on November 20, González de Haedo decided to formalize the possession of Rapa Nui in the name of the Spanish monarch Charles III, and ordered 125 marines and 125 fully armed seamen instructed in musketry, as well as a few Catholic priests in full religious dress with three wooden crosses, to land in Hanga Ho'onu bay. On shore, the Spanish were met by hundreds of Rapanui who joined the procession, dancing and singing and responding ora pro nobis to the Catholic priests' litanies along with everyone else as they marched across the north coast straight to Poike peninsula. Here the Spanish planned to erect the crosses, one on each of the three trachyte domes of Pua Katiki volcano, right where the most important astronomer-priests lived. As the procession advanced with banners flying and drums beating, they met up with the inhabitants of the Rapanui settlements they passed on the way who offered cloaks to the Catholic priests, as well as hens and pullets (symbols of fertility), crying Make Make, the name of the Rapanui creator god. Undoubtedly the Rapanui were not merely mimicking the behaviour of the Spanish, but were aware of the religious character of these activities; and since everything seemed to coincide with what the Rapanui considered sacred, it is no wonder they were more than happy to follow along, most evidently with a very different interpretation of the same events. Once the procession arrived at the domes on Pua Katiki volcano, the Spanish dug holes to set up the crosses, whereupon, according to their account, an abundant spring of water burst out from the one in the middle dome (a miraculous event that is hard to believe considering the nature of the terrain). After reading a proclamation, the Catholic priests then proceeded to perform blessings by chanting in Latin next to each of the crosses, which were simultaneously raised on all three mounds (see Fig. 1). Meanwhile, the Spanish officers took possession of the island with all due formalities handing the Rapanui chiefs or priests an official document to sign, which they did with markings of their own design (some drew petroglyph-like birds, others just lines $\dagger$ ). Everyone then cheered the king seven times, which was followed by a triple volley of musketry from the whole party, and 21 guns from the ship, something that understandably terrified the Rapanui. After taking possession, the Spanish climbed down Poike Peninsula, walked back to Hanga Hoonu, returned to their ship and left on the afternoon of the next day.

Interestingly, none of the Spanish explorers mentioned the three Rapanui ceremonial platforms that already stood on the top of these three mounds, especially since they recorded all other religious structures they passed on the way there. Since it seems unlikely that they were in disrepair, it is possible that the Spanish simply overlooked them, favouring their own activities instead. Nevertheless, what was so easily ignored by the Spanish is precisely what would have made these events all the more memorable for the Rapanui. The fact that these strangers arrived at the right time and carried out their official ceremonies and religious blessings at the 'right place', flaunting their 'superiority' and 'power', was a small coincidence that must have had great repercussions for the

$\dagger$ Other Polynesians may have developed a form of writing, but the Rapanui are the only ones who can prove it. Twenty-eight different objects exist that have rongorongo figures carved on them (mainly wooden tablets, but also small stones, staffs of power, breastplates, and votive figures). Attempts to decipher rongorongo have not been successful although it is evidently pictographic and written in reverse boustrophedon style. Some scholars suggest that the Rapanui invented it after European contact, possibly after the arrival of the Spanish in 1770. According to Rapanui oral tradition, rongorongo script was developed by chief Ngaara I, who was paramount chief at the time of Spanish contact, and it was he who set up several rongorongo schools in different parts of the island in the early 1800s. Unfortunately the script was lost when diseases killed all those who knew how to write or read it. 


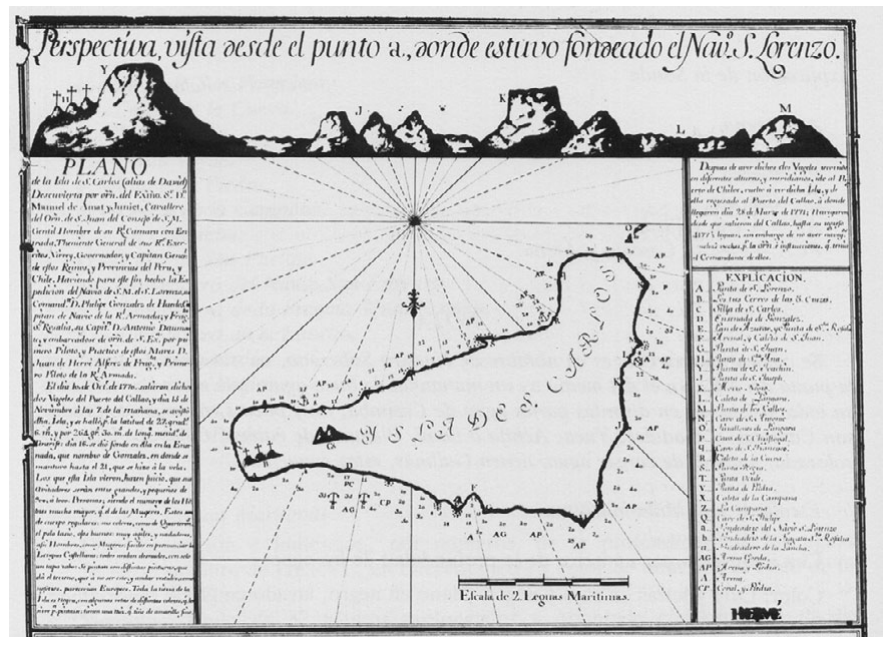

Figure 1. Map of Easter Island drawn in 1772 by the Spanish expedition commanded by Felipe González de Haedo. At the top left one can see the Poike peninsula and its three lava domes.

Rapanui. The sacredness of the astronomer-priests' dwellings and ceremonial platforms must have increased considerably as a result of the Spanish explorers' visit, although it is uncertain how it affected the social organization of the island and the power of the chiefs and priests in the years that followed.

\section{References}

Buck, P. H. [Te Rangi Hiroa] 1938, Ethnology of Mangareva, Bulletin 58, Bernice P. Bishop Museum, Honolulu.

Handy, E. S. C. 1927, Polynesian Religion, Bernice P. Bishop Museum, Honolulu.

Collocott, E. E. V. J. 1922, Tongan Astronomy and Calendar, Occasional Papers 8, Bernice P. Bishop Museum, Honolulu.

Cruchet, L. 2009, L'archéoastronomie des Îles Australes: Raivavae, Tupuai et Rurutu, Matari`i no. 26, Tahiti.

Edwards E. 1987, The Archaeological Survey of Faaroa Valley, Raiatea, French Polynesia. Inventaire Archéologique de Polynésie Française, Departement d'Archéologie, Centre Polinésien de Sciences Humaines 'Te Anavaharau', Punauia, Tahiti. Unpublished report.

Edwards, E. 2003, Raivavae. Archaeological Survey of Raivavae, Austral Islands, French Polynesia. Inventaire Archéologique de Polynésie Française, Departement d'Archéologie, Centre Polinésien de Sciences Humaines 'Te Anavaharau', Punauia, Tahiti. Easter Island Foundation Publications, Los Osos CA.

Ferdon, E. N. 1987, Early Tonga, as the Explorers saw it. 1616-1810, University of Arizona Press, Tucson.

Kirch, P. V. 2004a, Temple sites in Kahikinui, Maui, Hawaiian Islands: their orientations decoded. Antiquity 78, 102-114.

Kirch, P. V. 2004b, Solstice observations in Mangareva, French Polynesia. Archeoastronomy: the Journal of Astronomy in Culture 18, 1-9.

Kirch, P. V. \& Green R. C. 2001, Hawaiiki, Ancestral Polynesia. An Essay in Historical Anthropology, Cambridge University Press, Cambridge.

Mellen Bianco, F. 1986, Manuscritos y Documentos Españoles para la Historia de Isla de Pascua, Biblioteca CEHOPU, Madrid.

Ruggles, C. L. N. 2007, Cosmology, calendar, and temple orientations in ancient Hawai'i. In C. L. N. Ruggles \& G. Urton (eds), Skywatching in the Ancient World. New Perspectives in Cultural Astronomy, University Press of Colorado, Boulder, pp. 287-329.

Ruggles, C. L. N. 2010, Case study 4.2: Atituiti Ruga, Mangareva, French Polynesia. In C. L. N. Ruggles \& M. Cotte (eds), Heritage Sites of Astronomy and Archaeoastronomy in the Context of the UNESCO World Heritage Convention: a Thematic Study, ICOMOS-IAU, Paris, pp. 74-76.

Tragear, E. 1891, The Maori-Polynesian Comparative Dictionary, Lyon \& Blair, Wellington. 